\title{
Pansofie v díle Jana Ámose Komenského
}

\section{Jana Dlouhá}

Envigogika 2007/II/2 - Recenzované články/ Reviewed Papers

Publikováno/Published 31. 08. 2007

DOI: http://dx.doi.org/10.14712/18023061.18

\section{Abstrakt:}

Zvláštní atributy celostního vědění, jejich kontrast $s$ dobovým kontextem $v$ počátcích novověkého myšlení.

Stručná analýza těch Komenského myšlenek, které souvisejí $s$ jeho systémem pansofie - zakládají možnost jednotného vědění, a zdůrazňují rozměr péče o duši, svět, prírodu

\section{Klíčová slova:}

Univerzalismus ve vědě, harmonie, synkrisis, pansofické principy, univerzální vzdělání

\section{Abstract:}

Specific attributes of universal knowledge contrasting with contemporary context in the origins of modernity.

This article is a brief analysis of the universalist philosophy of Jan Amos Comenius. The principles of harmony in which his system of pansophia is rooted emphasize the dimension of care for spirit, world and nature.

\section{Key words:} education

Universalism in science, harmony, synkrisis, pansophic principles, universal 


\section{Úvod}

Myšlenka univerzální vědy, vybudovaná na metodicky jednotném základě, je jedním z velkých filozofických motivů, které prostupují celé 17. století (od Bacona až po Leibnize). $\mathrm{V}$ tomto období, charakterizovaném vědeckými úspěchy (především matematická prírodověda, moderní státovědecké teorie, historická metodologie), Jan Amos Komenský navazuje na jednu z nejstarších filozofických myšlenek, myšlenku o všeobecné harmonii, kterou se zabývali nejrůznější myslitelé starověku i středověku a kterou oživil Mikuláš Kusánský. ${ }^{1}$ Na tomto základě Komenský postupně buduje svou originální filozofii a vlastní systém pedagogický, jež často odporují radikálním proměnám vmyšlení 16. a 17. století. Vzniká tak další univerzální koncept racionalistický, který však zưstává stranou hlavního myšlenkového zájmu té doby (Patočka, 1997, s. 172; s. 138-142). Komenský vněm totiž implicitně odmítá trendy své doby, kterou Ize charakterizovat jako počátek tzv. vědecké, resp. vědecko-filozofické revoluce a kterou provází rozchod světa hodnot a světa faktů (Janoušek, 2005).

Ve svém díle vypracoval Komenský soustavný základ a oporu pro nauku o výchově, které poskytl také orientaci hlavních pojmů (Patočka, 1997, s. 139). Jeho postupně vytvářený systém pansofie, univerzální vědy o všem a pro všechny, měl však být nejen uspořádaným výběrem poznatků o světě, přístupným chápání všech lidí, ale také sjednocujícím prvkem lidského společenství. ${ }^{2}$ " Měl obsahovat znalosti nezbytné k tomu, aby člověk mohl žít důstojně na zemi a dovršit pak svou existenci $v$ životě posmrtném. Pansofický systém tak představuje $v$ Komenského díle vyšší stupeň řešení problému jak zprostředkovávat poznatky o světě - je zde prítomna právě tato dimenze lidského života vcelku, v níž se ukazuje člověku smysl veškerenstva. Tak je teprve možné rozumové pochopení toho, co je člověku bytostné, k čemu je určen - což pak vymezuje a ohraničuje naši vưli (Patočka, 2002, s. 206).

Komenského pansofické projekty programově a metodologicky zahajují díla Předehry snah Komenského a Předchůdce vševědy. ${ }^{3} \mathrm{Na}$ ně brzy navázal ve spise Cesta světla, v němž shrnul a sestavil reformní návrhy na úlohu pansofie, škol a jazyka ve společnosti (světlem Komenský zde i jinde rozumí vědění). Pozdější díla pansofická nabývají rozměru všenápravného stále více - Komenský nabývá přesvědčení, že společnost je možno

\footnotetext{
1 Především díky Mikuláši Kusánskému, renesančnímu filozofu a všestrannému učenci, se Komenský zabývá těmi atributy jsoucna, které mu přisuzují vlastní bytnost (byt' k Bohu zaměřenou, jeho rádem orientovanou). Nedovolují tak z něj učinit pouhou inertní hmotu vystavenou Božské vůli, později př́rodním zákonům.//Z Aristotela vycházející ontologie totiž tradičně podává čtyři odpovědi na otázku po původu jsoucna, a to vymezením příčin pohybu, který je uskutečňuje. Jsou jimi tzv. causa materialis, causa formalis, causa efficiens a causa finalis. Za principiální se později považuje pouze dvojí složka, a to látková a tvarová. V př́rodním jsoucnu tak vládne jediná, vnitřní zákonitost, zákonitost tvaru, který každou věc utváří a řídí k jejímu účelu.//Mikuláš Kusánský naopak ale říká, že v každém konkrétu je ještě svazek obojího - tedy láska a harmonie. Forma tak přestává být sama sebou aktivní dirigující silou. (Patočka, 1997, s. 63-64)

2 Základem osvíceného věku bude obecná filozofie stavějící lidskému rozumu před oči plně, spořádaně a pravdivě všechno, cokoli kde je. Aby, jako moudrost Boží vidí a pořádá všechno, jsouc jediná, také lidská moudrost (otisk božské) byla jediná, nerozdělená na vědy, umění, dovednosti. [...] Nová filozofie má tedy u nás poslední, nový, cíl, tj. smírení rozporů nalezením, ustálením a osvětlením pravých idejí všech věcí, aby se aplikací všeho částečného k těmto idejím hned ukázalo, cokoli se shoduje nebo neshoduje, a abychom měli cestu ke shodě." (Komenský, 1992e, s. 332)..

${ }^{3} \mathrm{O}$ vydání těchto děl se zasloužil Samuel Hartlib, Němec, který se $v$ tehdejší Anglii zabýval organizací vědeckého života. Komenský mu roku 1637 posílá první náčrt svých pansofických idejí, a Hartlib je inned vydává s názvem Conatuum Comenianorum praeludia (Předehry snah Komenského). Již zde Komenský teoreticky podává program vytvoření jednotné vědy a uceleného obsahu vzdělání. Dílo Prodromus pansophiae (Předchůdce vševědy) pak bylo vydáno r. 1639 v Oxfordu. Cesta světla, Via lucis, vzniká mezi lety 1641-1642.
} 
napravit, uvést do ideálních poměrů na základě osvěty a vzdělání ve všech potřebných věcech pro všechny lidi bez jakýchkoliv omezení. Vzdělání znamená poznání pravdy a tato znalost je pak předpokladem urovnání veškerých sporů mezi jednotlivými lidmi ve všech oblastech jejich činnosti. $\mathrm{K}$ tomu ovšem musí pansofie vyložit všechno $\mathrm{s}$ takovou přesvědčivostí, že budou vyloučeny veškeré námitky.

Základní pansofické dílo, Pansofia, třetí kniha Všeobecné porady o nápravě věcí lidských ${ }^{4}$, shrnuje pansofické myšlenky a podává výklad o tom, co jsou lidské věci a jak jsou narušeny. Závěrečná část Pansofie popisuje plody všeobecného vědění, jeho užitek v různých oblastech. Předjímají to, co je pak obsahem následujících knih Všeobecné porady $i^{5}$ završením celého pansofického úsilí je Panorthosia (Všenáprava). V kontextu tohoto díla Komenský tedy již klade důraz nejen na výchovné a vyučovací metody (jak tomu bylo $v$ jeho díle ryze pedagogickém), ale především na obsah a celkové cíle vzdělání. Jeho smysl nachází ve všeobecné nápravě: člověk je pokračovatelem stvořitelského díla Božího, v nápravném díle naplňuje svůj biblický obraz bytosti, již Bůh stvořil ke svému vlastnímu obrazu.

Reformátorské myšlenky Komenského vyniknou zvláště v dobovém kontextu: od 40. let 17. století byly totiž přímo konfrontovány s filozofií hlavního protagonisty racionalizmu, René Descarta. Ke shodě mezi těmito mysliteli nikdy nedošlo: nedohodli se ani při osobním setkání vr. 1642. Ačkoli oba směřovali k jednotné vědě, Descartes odmítl Komenského nauku stím, že směšuje věci lidské a božské a že se zabývá př́liš mnoha věcmi. Naopak Komenský, ačkoli se pokoušel začlenit do svého systému moderní postupy včetně Descartesovy analyticko-syntetické metody, má stále na mysli celek, který by poznání o světě nejen shrnoval, vykládal, ale umožňoval také lidskou účast na světovém dění (Válka, 1996). Komenského dílo tak zůstává jednou z podob nedescartovské alternativy evropské filozofie 17 . století.

\section{Vševěda}

O jednotné vědě přemýšlela řada myslitelů oné doby: mezi jinými Descartes, později Leibniz. Všichni o této vědě mluvili v rưzných, často radikálně odlišných pojetích a verzích. Descartesova mathesis universalis byla ovšem metodicky i svým záběrem založena zcela jinak, než pansofie Komenského. Měla vyhrazenu vlastní oblast, tedy se nepřekrývala s dalšími obory, především s teologií, a to svým předmětem ani metodou. Přísně oddělovala různé sféry myšlení: úkolem filozofie, zvláště její metafyzické části, pak bylo překlenout konflikty "světového názoru”, kde vstupuje do hry morálka iracionalita.

4 Comenius, Jan Amos. De rerum humanarum emendatione consultatio catholica. 1. vyd. Praha: Academia, 1966. (latinsky) //Řecké slovo nav znamená vše či všezahrnující, бopia znamená moudrost. Slovo Pansofia sám Komenský vykládá jako Všeobecná moudrost - jde o univerzální poznání všeho. Ovšem jeho Pansofie je postavena spíše na myšlence nápravy lidských věcí. Komenský dělí nápravné dílo do tř́ oblastí: vědění, společenské uspořádání a náboženský život - je třeba napravovat školy, politiku, církev.//V Pansofii Komenský na základě novoplatónské emanační teorie dělí svět na čtyři stupně (čtyři pansofické světy) - sestupně od světa možného, přes svět archetypů a svět andělský až po upadlý svět hmotný, který je iniciován stvořením tři principů: hmoty, ducha a světla (materia, spiritus et lux), jejichž vzájemným prostupováním a interakcemi vzniká stupnice vždy vyšších forem jsoucna - elementy, páry, nerosty, rostliny, živočichové a člověk. Tento vzestupný proces nazývá Komenský "dílem prírody" (opus naturae). Člověk, jakožto vrchol rozvoje př́rody, je pak spolutvưrcem dalších tří pansofických světů - světa tvorby (mundus artificialis), světa morálního (mundus moralis) a světa duchovního (mundus spiritualis), který je předstupněm posledního světa pansofického, světa věčného (mundus aeternus), v němž se vše vrací zpět k Bohu.

${ }^{5}$ patří sem Pampaedia (Vševýchova); Panglottia (Všemluva - jde zde o zdokonalení jazyka, aby jím mohla být pansofie tlumočena)

6 Metodicky zůstává Komenský věrný předznamenané harmonii, jež je založena $v$ analogizmu. Již předklasické myšlení takto postupovalo: od známého k neznámému, vyvozovalo závěry na základě podobnosti či identity. 
Naopak Komenského vševěda harmonicky integrovala vědu společně svírou do jednoho celku (Dokulil, 1996). Spoléhala na jistou koncepci světa a pojmu př́rody - kdy veškerá realita je stále obměňovanou realizací téhož základního plánu. ${ }^{8}$ Takový svět pak mưže být pochopitelný jednotným způsobem, na základě jednotné metody. Věda vněm není roztř́ššěna $v$ jednotlivé, nezávislé, metodicky odlišné disciplíny. Tvoří soustavný celek - stává se vševědou. Pansofie měla být na rozdíl od theosofie "poznáním, které procházejíc světem, dopracovává se Boha". ${ }^{9}$

Komenský ve své Vševědě propracoval stará témata, ale také je prohloubil mnohostranným pojetím myšlenky univerzálního celku (Patočka, 2003, s. 208-209). Smyslem filozofie je uspořádání (zde se Komenský odvolává na Aristotela) - aby se člověk mohl vyznat v množství věcí, jež má poznávat, vcelku světa, je třeba toto množství třídit podle řádu (ordo), jimž jsou spojeny $\mathrm{v}$ celek, a tak pronikat $\mathrm{k}$ pravdě (veritas), k pravdivému poznání. Multitudo - ordo - veritas je výchozí triáda principu pro myšlení, které má budovat Svět možného. Znamená: východiskem z chaosu mnohosti je určitý rád (ordo). Všechno má své místo vcelku světa podle řádu světa; každá jednotlivina má i své vnitřní uspořádání, strukturu, vnitřní řád, který způsobuje, že tvoří celek. Komenský nazývá toto vnitřní uspořádání schematizmus. V rámci vševědy chce Komenský vědomě hledat ve všem, co existuje, stopu absolutna (Čapková, 1999, s. 102).

„Pansofie musí být zpracována tak dokonale, aby ve srovnání s ní se mohlo všechno jevit jako chaos, zatímco ona jediná byla podobná úplné soustavě Boží, stroji světa. Pansofie, přivedená na výši dokonalosti, byla by normou všech odborných knih, podobně, jako díla př́rody jsou normou všeho, co vzniká mocí lidské dovednosti. Formou, normou a základem pansofie bude světlo myslí, pořadí věcí sestupujících od nejvyšších tříd k podřazeným druhům. Toto pořadí je sice nepochybné samo osobě, nikoli však také nám pro naši nevšímavost." (Komenský I, 1992, s. 57).

Pro Jana Amose Komenského je východiskem univerzální vědy první filozofie, 10 zakládající rozvrh možného jsoucna, který je pak různě uskutečněn ve světě materiálním a v dalších světech (lidský, politický, historický, náboženský a konečně úhrnný svět věčný). Pod vlivem Descarta přetvořil Komenský toto pojetí tak, že první filozofie je základním obsahem naší myšlenky (cogitatio), dále svět "vzorný" je nekonečným jsoucnem a další světy znamenají sestup z věčnosti do času a hmotného univerza, jehož vrcholkem je člověk; pak následuje návrat opět k vyššímu (svět práce, tvořivosti, svět morální a nakonec svět věčný) (Patočka, 1997, s. 145-146). Na základě analogie pak všecko věcné poznání může být vyvozeno z nejhlubších základů samotné přírody, jednotných a pevných. Produktem této myšlenky je pansofická encyklopedie a na ní je postavena také didaktika (Patočka, 1997, s. 171-175).

\footnotetext{
7 „Jaký je rozdíl mezi filozofií a pansofií. Takový, jako mezi částí a celkem; nejinak, než jako by někdo žil v nějakém zámku a měl klíče jen od několika komnat, zatímco jiný by měl jen jediný, otevírající všechny." (Komenský, 1992e, s. 336).

8 Komenský zde představuje veškerenstvo jakožto cyklus světů, cyklický systém světových vrstev, které jsou zvnějšku i vnitřně organicky konzistentní. Přitom podstatou celé Pansofie je svět možný neboli ideální, Mundus possibilis, úplná a dobře uspořádaná soustava myšlenek. Další světy jsou postupným úpadkem a degenerací; teprve ve světě věčném se vše vrací zpět $k$ Bohu. Viz http://cs.wikipedia.org/wiki/Pansofia

9 Theosofie se snaží poznat svět „zevnitř, ze světového centra, z centra našeho bytí a dění. Naopak $z$ vnějšku, postupem do centra a prodíraje se $k$ němu vždy hloub, chce si vymoci tento smysl pansofie." (Patočka, 1997, s. 18.). Patočka zde odkazuje na dílo PEUCKERT, W. E. Pansophie : Ein Versuch zur Geschichte der weißen und schwarzen Magie. Stuttgart : Kohlhammer, 1936.

10 Po zpracování První filozofie, knihy, kterou Komenský nevydal, začal teprve promýšlet problémy pansofie. Východiskem byla práce na Dveř́ch věcí - základem metody pansofie je zde pansofická metafyzika. $V$ tomto pojetí je metafyzika definována jako všeobecná věda, na jejíž principy lze převést a od ní zase odvozovat pojmy a poučky speciálních věd. Metafyzika je tak východiskem pansofie, "vědou před fyzikou", nikoli za fyzikou, jak ji chápal Aristoteles (Pešková, 1991).
} 
„Je třeba sestavit pansofické pandekty. Bůh umístil v př́rodě všechno, co může být idejí našich světů (tedy nejen světa lidské dovednosti, nýbrž i světa mravního - ctností a hř́chů - a také světa duchovního ...). Proto by bylo dobře rozvést dle jednotlivých témat celý obsah prírody, to jest obsah knihy světa i knihy Písem a také knihy vlastního vědomí. [...] Tak by bylo možno využít vlastností všech věcí v prírodě (také těch, které se dosud zdály úplně bezcenné) $\mathrm{k}$ odhalení tajemství věd, moudrosti, zbožnosti a věčnosti, se svrchovaným vkusem a užitkem." (Komenský, 1992a, s. 57).

Komenského pansofie čili vševěda je uceleně a přehledně uspořádaným systémem vědění, které ( $v$ oblasti prírodních věd, poznání člověka i Boha) má v zásadě bezrozpornou povahu. Všemoudrost je souladným celkem; ${ }^{11}$ pansofie má podávat poznatky určitým způsobem souvisejíć, uspořádané podle přirozeného řádu. Univerzálnosti má být dosaženo vyvozováním z několika či jednoho principu.

„A je-li všude nepřetržitá řada příčin a následků, musíme nezbytně dospět k nějakému prvnímu poslednímu článku tohoto řetězu, jímž tak veliká spojitost věcí začíná a jímž i končí. Tvrdím, že je nezbytné dostat se $k$ první příčině, $k$ činiteli všech činitelů, $k$ formě všech forem, $k$ cíli všech cílů, $k$ němuž všechno směřuje, a v němž toto všechno, i samo veškerenstvo, spočine $v$ klidu. Poruš ten řád a veškerenstvo se změní $v$ chaos a bláznivý rej." (Komenský, 1992a, s. 323).

Prostý encyklopedický plán, pořádající dostupné vědění podle přirozených principů, však Komenského filozofie překonává poukazem k celkovému smyslu.

„Svět si sám nepostačí, veškerenstvo je uspořádáno tak, aby každý jeho úd a každá vrstva poukazovaly mimo sebe $k$ dalším a vyšším vrstvám, ale také tento celek není sám o sobě postačující, poukazuje nad svět, kde teprve Ize spatřovat jeho pravý smysl. [...] Ve světě je třeba existovat a působit ve shodě $\mathrm{s}$ jeho celkovým smyslem, který leží mimo něj. Tak se ukazuje, že cesta k nápravě světa vede přes filozofii školy, filozofii výchovy. [...] Škola a výchova, která je hodna toho jména, musí vždy přehlížet univerzální celek světa $v$ jeho soustavném smyslu, to znamená, že musí mít tento celek v hlavních rysech stále na zřeteli. [...] Tento souvislý celek musí být $\mathrm{k}$ novému účelu obsáhnut také novým věděním. Toto vědění nemůže již být tradičním roztříštěným, kusým věděním $v$ izolovaných disciplínách. Nemůže mu již běžet o pouhou znalost, nýbrž o celkovou moudrost. Proto musí být jednotné." (Patočka, 1997, s. 181-3).

Pansofii tak Komenský chápe především jako filozofické úsilí o celkový názor člověka na svět, názor na život i smrt, který by mohl přijmout každý člověk a který by ho mohl vést a ř́dit po celý život, všude a vždy. $V$ tomto uspořádání se pak také člověk nemǔže stát izolovanou duchovní substancí, jíž je odepřena živá interakce s prostředím přírodním a společenským (Pešková, 2000, s. 43).

Tím se pansofie Komenského liší od pouhého encyklopedizmu: není sumou mechanicky uspořádaných vědeckých poznatků, ale rozvrhem vědění podle univerzálního rádu bytí, které musí být základem pedagogické teorie i praxe. Pansofie znamená porozumění celku a řádu světa sub specie aeterni. ${ }^{12}$ Zahrnuje tak systematickou myšlenku vědění úplně věcně sjednoceného, prošlého sítem jednotného metodického postupu a redukovaného na podstatnou, nejstručnější složku (na zcela podstatné věci). $V$ této soustavě se ve jménu dílčích poznatků nesmí zapomínat na obzor jednoty světa jako půdy pro poznání - celek musí vždy tanout na mysli (Pešková, 1991).

\footnotetext{
11 "Všemoudrost je souladný celek, celost ve všem a všude. Hlavním úkolem života, a tudíž i myšlení, vůbec je pořádek; pansofie má podávati poznatky jeden s druhým souvisejícím určitým řádem [...]." Pešková (2000) zde odkazuje na: Tomáš G. Masaryk. J. A. Komenský. Praha, 1920. Přednáška. s. 6.) 12 "Pro mě je však dostatečně vševědoucí ten, kdo procházeje světem - dokonce světy - naučil se nedat se zmást žádným množstvím a žádnou rozmanitostí věcí a tak nesejít z cesty vedoucí k prameni všeho dobra." (Komenský, 1992d, s. 479).
} 


\section{Souvislosti pansofie, její zvláštní znaky}

Celek vědění, který dílčí, konkrétní poznání, přesahuje, není samozřejmou součástí skutečnosti; je garantován teprve jistým úsilím. Jednotu skutečnosti lze myslet bezrozporně, pokud je základem víra v absolutní zřídlo této jednoty, jak se však bude jevit z pohledu doby, ve které se důvěra v metafyzické zdroje vytratila?

„Skutečnost nám nikdy není odhalena celistvě. V porozumění celku se setkáváme s jednotlivostmi, ale porozumění celku, bytí, se skrývá v porozumění jednotlivostem. Ty jsou odhaleny vždy jen z určitého hlediska, je to porozumění vždy pro jednotlivou stránku, v jistém aspektu, v jisté situaci. Jsoucno vcelku a bytí [...] je ve své podstatě tajemstvím." (Patočka, 1995 s.117).

Pansofie Komenského nejen soustavně pořádá dostupné poznání, poukazuje také $\mathrm{k}$ jeho smyslu. Především v tomto ohledu odkazuje $\mathrm{k}$ jisté formě celkovosti, kterou zakládá transcendentně. Vztah k celku je nepominutelnou součástí systému vědění, kterému nejde o vědění samo, které není odtržené od žitého světa člověka a má vést $k$ nápravě věcí lidských. V tomto světle je zajímavé poukázat nejen na filozofická východiska vševědy, kterou Komenský systematicky ve svém díle rozvíjel, ale i na některé její metody a prostředky.

\section{Zkušenost}

Má-li být stavba světa pojata do lidské mysli, bude třeba získat základní ideje, $z$ nichž je každá vrstva reality sestavena jako věty a slova $z$ hlásek. $K$ této abecedě reality máme přístup bezprostředním smyslovým dojmem; nejbližší pưdou a předmětem lidského ducha, od něhož indukcí postupujeme, je příroda13 (Patočka, 1997, s. 266). Pro poznávání je nezbytná př́tomnost věcí samých, jak jsou dány ve své realitě; Komenský na prvním místě rozpracovává metodiku smyslového nazírání a pozorování, teprve potom myšlenkového výkladu. Názor pramení z pưvodního a originálního styku se jsoucnem a je pevnou pưdou a branou všeho poznání v několika ohledech: jako jeho základ a pưvod, bez něhož poznání není možné; jako norma vší pravdy; jako nenahraditelný pramen vlastní zkušenosti. Věda je pak vnitřním nazíráním věcí - vnější smysly odevzdávají svůj předmět vnitřním, myšlení jej rozebírá a světlo mysli prosvěcuje. Člověk se tedy má seznámit se samou skutečností přírody, jež je základní „knihou Boží” (Patočka, 1997, s. 292-294).

Komenský nemá pochybnosti, co se týká smyslového vnímání; ${ }^{14}$ to nám totiž „bezprostředně vtiskuje pravdu, jež je vtisknuta věcem, i když kvůli různým zmatkům

13 „Poučky mají vztah k rozumu, příklady k smyslům. Smysly jsou však dřive než rozum. (Není $v$ oblasti rozumu, co dř́ve nebylo $v$ oblasti smyslů.) Co se tedy dotýká smyslů, necht' postupuje vpředu a co utváří rozum, necht' následuje." KOMENSKÝ, J.A. Vybrané spisy Komenského : II. díl. Praha: Dědictví Komenského, 1908. [Kapitola] 10, Didaktika analytická. Překlad A. Krejčí. Původní dílo Linguarum methodus novissima, 1644-1657. Hypertextová verze dostupná z WWW: <http://www.karlin.mff.cuni.cz/katedry/kdm/studijni materialy/komensky didaktika.txt>.

${ }_{14}$ Metodicky postupuje Komenský od známého k neznámému př́mým stykem smyslù, nebo ducha. Je si „,...] předně vědom sochy, od níž berou čidla popud; dále úkonu, jímž se poznání děje; naposledy, skrze úkon, je si vědom sebe; ab esse ad nosse valet consequentia." (Pujman, 1942, s. 1-2).//Jak na stejné nazírá Descartes - střízlivý pěstitel spekulace, kterému spíše než o člověka šlo jen o abstraktní myšlenku o něm, zníž lze odvodit jisté apriorní konstrukce? Postupuje od známého k neznámému přes rovnítko, rovnicemi, shodností; a úměrami, podobností. Jenom dozírá, jak se ten pochod děje - a to tak, aby nerušil. Vtom se shoduje s Baconem, že "rozum lidský má být světla suchého, a nepřijímat příměs od vưle a vášní, zčehož pocházejí vědy libovolně sestrojené" (Pujman, 1942, s. 14).//Descartes tak chce odhalit jednu vlastnost Božské podstaty "per intuitum intelligo": úkonem, jenž na smysly se neváže (Pujman, 1942, s. 3). Poznávat tedy značí (i pro Descartesa) najít, nebo ověřovat řád (Pujman, 1942, s. 4). Řád však je zde obezřetný výběr; k němu patří (Descartesovy) pomyslné bytosti (Pujman, 1942, s. 5). Vytváŕí tak množný řád [...] bez jakosti. Bytnost (věcí) smysly čitelná v řád onen ani nevstupuje (Pujman, 1942, s.3).//Na druhé straně Komenský ve světě lidském 
a vzdálenosti věcí je potřeba přibrat na pomoc rozum. Principy poznání je ovšem třeba spojit tak, aby [...] Zjevení nám poskytlo víru, rozum pochopení a smysly jistotu." (Dokulil, 1996). Komenský tak požaduje, aby se poznání opíralo o tři prameny, tj. smysly, rozum a víru: rozum má korigovat smyslové poznání, víra poznání rozumové.

\section{Harmonie}

Jednotná věda Komenského spočívá na odlišném základě, než je tomu u Descarta. Inspirací pro vytvoření originální myšlenkové soustavy byla Komenskému filozofie Mikuláše Kusánského, především jeho myšlenka absolutní jednoty, jejíz je svět pouhým zmnožením a zkalením. ${ }^{15}$

Základem pansofického názoru Komenského je myšlenka, že svět je jednotným celkem, který sestává z nestejných, ale vzájemně souvisejících vrstev. Jsou budovány na základě analogie a panují mezi nimi vztahy harmonie. Tento paralelizmus je vidět $i$ ve srovnávání jevů prírody, řemesel a výchovy, které mají společné obecné principy. Komenský se tedy obrací k př́rodě, aby z ní čerpal své "neklamné základy” (Kopecký a kol., 1969).

Panharmonické myšlence přikládal Komenský zvláštní význam; je pro něj [...] [...] [...]. Myšlenky harmonie je možno použít jako nástroje racionalizace, a to ve způsobu všeobecné katalogizace, zpřehlednění, utř́́dění. Potom neznámé Ize pochopit podle analogie - rovnosti vztahů mezi strukturami známými (Patočka, 1997, s. 141-142). Harmonický souvztah je pořádajícím principem poznání, který umožňuje vypracovat Komenskému pansofii - je její metodou (Patočka, 2003, s. 51).

Panharmonie je důležitým východiskem „první filozofie”, podávající plán možného jsoucna vůbec, které je pak různě uskutečněno $v$ různých světech; mezi nimi vládne paralelizmus (Patočka, 1997, s. 145). To působí, že svět je složitá, ale harmonická stavba; údaje jedné vrstvy mají význam pro všecky ostatní a všecky vrstvy jsou výrazem téže zákonnosti, kombinace týchž prvků. $Z$ tohoto důvodu je nejen možné, nýbrž nutné a doporučeníhodné, aby zákonitosti jednoho "světa" byly přenášeny do jiných "světư". Př́kladem harmonického vztahu je i vztah mezi prírodou a uměním, rưznými ráády dovedností (Patočka, 1997, s. 186). Podrobnější rozvinutí vztahu natura-ars, řádu daného a řádu člověku uloženého a jím zprostředkovaného je také jedním z ústředních filozofických témat Didaktiky, jež směřuje k výchovné praxi (Patočka, 1998, s. 231).

Význam panharmonické myšlenky je především v poukazu ke smyslu veškerenstva; úkolem pansofie je pak přiznat člověku místo, které mu náleží. ${ }^{16}$ "Ve světě lidském ale

„[...] putuje stejnou cestou, jako lidé; vždy při nich stojí [...] Každého člověka pokládá za výtah světa[...]" (Pujman, 1942, s. 5). Možná tak Ize Komenského nazvat jménem vjeho době neobvyklým fenomenolog (Pujman, 1942, s. 11).//Descartes obsáhne svět jenom zkratkou, nekonečných rozloh opakem (Pujman, 1942, s. 5). Bude tedy u něj vždy jenom část; u Komenského však - „pastýře jednot v rozptýlení" - celek. (Viz též Jana Amose Komenského Vlastní životopis ze spisu: pokračování $v$ bratrském napomínání Samuela Maresia o mírnění horlivosti láskou. Přeložil dr. Jos. Hendrich. Praha

: Ústřední nakladatelství a knihkupectví učitelstva československého,Eduad Grégr a syn, 1924. s. 132).

15 Základním principem je zde splynutí protikladů (coincidentia oppositorum v absolutnu Boží bytosti); "explikace" těchto protikladů, jejich uplatnění ve světě není nikdy čisté, ryzí a je překlenuto jednotou. Proto je možno říci, že svět je harmonie, ovšem harmonie protikladů, které se stýkají, mísí, temperují rozmanitými vztahy (Patočka, 1997, s. 60-61).//"Vědění lidské vzhledem k omezenosti, stvořenosti, konečnosti teprve mírí k vědění o celku. Naše lidská pravda se pouze blíží té, která jednou provždy, celkově a nade vši pochybnost jest a tvoří základ pro všechno jsoucno. Nejvyšším stupněm lidského vědění je proto pouhé negativní postižení tohoto faktu, poučená nevědomost. [...] Je křest́anského základu, který teprve umožňuje pochopit všecko. Hlavní normou křestáanské vševědy pak je všeobecná harmonie, v níž splývají protivy." (Patočka, 1997, s. 60-61).

16 Toto naplnění člověka smyslem veškerenstva, toto odpovídání mezi člověkem a jsoucnem vcelku bude znamenat, že vưle člověka bude ovládána rozumovým pochopením toho, co je člověku bytostné 
harmonie neznamená pouhý soulad s tím, co jest, v jeho přirozené podobě - má je (toto jsoucí) doplňovat novými nálezy a nástroji, které slouží k jeho zdokonalování a zlepšování. V této filozofii se zráčí tvořivý duch protestantizmu (Patočka, 1998, s. 218).

Panharmonie Komenského obohacuje myšlenkový svět 17. století, i když zưstává stranou největšího myšlenkového zájmu té doby - vzniku matematické prírodovědy. Je ovšem základem velkého univerzálního racionalistického konceptu, který je v opozici vưči převládajícímu pohledu na prírodní skutečnost jako na velkorysý mechanizmus, kde se vše děje tvarem a pohybem. Význam panharmonické myšlenky nebyl (tehdy a není dosud) plně rozpoznán; její pravá síla spočívá především ve výuce a výchově. ${ }^{17}$

Vychovatelské umění musí být založeno na pevném řádu, jehož základ není zákon přírody $v$ moderně prírodovědeckém smyslu, nýbrž univerzální paralelizmus a analogie (Patočka, 1997, s. 140-148).

\section{Synkritická metoda}

Vzájemný vztah jednotlivých vrstev a celku skutečnosti zachovává pansofická metoda poznání, jejíž úlohou je sjednotit všechno lidské vědění. Předpoklad harmonického souladu mezi různými světy umožnil Komenskému vytvořit metodologii, která je kombinací analýzy, syntézy, a synkreze, logiky a analogie, apriorizmu a aposteriorizmu, vztahů obecného a zvláštního, celku a částí apod. Synkritický postup byl vlastní způsob Komenského, který znamenal metodu srovnávací, uplatňovanou $v$ různých rovinách a zaměřenou k odhalování podstaty skutečnosti (Čapková, 1992, s. 19).

„Konečně si také musejí vypomáhat tři metody. A tak syntéza ukazuje, zda analýza správně nalezla části celku, analýza zase zjištuje, zda syntéza uspořádala věci v úplnosti, a zda si přitom obě vedly dobře, to staví do správného světla synkreze (jež sdanou věcí srovnává jinou, podobnou a zřejmější), a to tím, že bud' odhaluje omyl, jehož se dopustila ta či ona strana, nebo zjištuje tutéž společnou pravdu, vystavuje ji otevřeněji světlu a zpevňuje tak duchovním prožitkem." (Komenský, 1992a, s. 173-177).

Tato tzv. synkrisis ${ }^{18}$ vede k završení porozumění, udržuje člověka ve světle. Jdeme-li synkritickou cestou, je našemu zraku vždy přístupen smysluplný celek světa, ve kterém

a k čemu je sám určen. Předpokládá to, že člověk musí překonat sklon k tomu, aby se považoval za jediné ústřední centrum všeho; musí se naučit podrobovat se tomu, co jej překonává a co mu vládne. Vševýchova pak př́mo odporuje tendenci dosazovat vlastní centrum za všeobecné; tato ústřední myšlenka je $v$ Komenského díle vybudována $v$ univerzalizmus. Znamená život nikoliv $v$ sobě a pro sebe, ale v celku, ve všech a ve všem. To vše spojeno svědomím významu dějinné chvíle před završením dějin - blíži se doba světla." (Patočka, 1998, s. 96-98; Patočka, 2003, s. 206-207).

17 "Komenský pochopil, že pravou racionalizační moc ve výchově má myšlenka harmonie, která teprve ukáže svou sílu. Pojme-li se univerzum z jejího hlediska, stane se v pravém smyslu školou života." (Patočka, 1997, s. 141-142).

18 Synkrisis - nereduktivní uvádění do vztahů, spojování a porovnávání, sjednocování, shrnutí s cílem obhlédnout a porovnat; druh syntézy; opozitum k diakrisis (oddělování). Záměrně uskutečňovanou synkrisis je synkritika, jejímž cílem je porovnávat to, co se uvádí do vzájemného vztahu; kritika a souběžná komparace. Zahrnuje analogické postupy; synkritická metoda je Komenského příspěvkem k metodologickému hledání 17. století. Viz též (Kyrášek, 1964).//Tato metoda na rozdíl od dedukce neodstupuje od skutečnosti, z konkrétního nevyvozuje abstraktní, ale zůstává při skutečnosti. Je to postup nemanipulativní, poskytuje cíle, normy, smysl, a uchopuje celistvost věcí a světa $v$ jejich významu a poslání. (Epistemologický) vhled do jádra skutečnosti, který je touto cestou dosažen, je nahlédnutím do společenství světa, do jediné panharmonické skutečnosti. V Komenského myšlení je synkrisis pưvodně odkázána na božský vklad, zajištúující jednotu a harmonii světa; tento svůj (ontologický) základ však v mnohém překračuje.//Metodologicky je synkrisis analogickým a komparativním postupem. Kterákoli částečka světa, nebo vrstva skutečnosti vypovídá o jediné harmonii; každá vrstva skutečnosti pak o univerzální analogii. Proto také smysly a to co jim je nejbliže - totiž príroda - poskytují znalost o podstatě ostatních vrstev, o světě v celku. Tak je člověku 
zůstává Tajemství, jež neodkazuje pouze k uchopitelnému a potom zmanipulovatelnému zvládnutí.

Synkrisis poskytuje pravý výhled a rozhled, ex-plikuje, vykládá skutečnost "spanile" a "líbezně". Komenský však nechápe synkrisis jako prostředek spekulativního myšlení anebo cestu $\mathrm{k}$ čiré kontemplaci - má být návodem $\mathrm{k}$ lidské aktivitě, $\mathrm{k}$ tomu, jak je třeba si $\checkmark$ žité skutečnosti počínat, jak pracovat, jak zacházet s lidmi i věcmi. Porozumění smyslu skutečnosti tak vede $k$ zákonitostem mravní povahy, $k$ důvěrnému seznámení se s posláním a úlohou člověka ve světě jako společném domově (FILIT, 1999).

\section{Kvalita}

Obecný základ veškerého vědění spočivá v metafyzice, ${ }^{19}$ která má podávat „principy všeho poznání, první jednoduché pojmy, jež jsou mysli vrozené, nebo jsou snadno poznatelné". Jsou to "první semena vědy", její prameny; od metafyziky lze pak požadovat uspořádání všech oborů. "Všechny vědy používají jistá obecná slova a jisté výroky [...] či zásady uvažování a posuzování. O nich však žádná zvěd nejedná zvlášt', nýbrž je přebírá z obecného a navyklého užívání a vyjadřování. [...] Poněvadž však ve všeobecném podání tato slova, výroky a zásady jen tak poletují mezi lidmi a jsou jedněmi užívány tak, druhými jinak, vzniká z toho neshoda, ba zmatení pojmů [...]" O své metafyzice je Komenský přesvědčen, že má předcházet poznání fyzického světa, být první filozofií. ${ }^{20}$ Protože uvažuje o obecných formách věcí, je možno dle jejích principư veškeré vědění uspořádat; současně tak má otevírat cestu k pochopení všech předmětů najednou. Ukazuje tedy, "co, prostřednictvím čeho a jak jedna a každá věc je." (Klosová, Schifferová, 1999).

Formy věcí však nejsou pouhými myšlenkovými formami, „otevírají př́ístup nejen ke slupce slov, nýbrž i $k$ jádru věcí samých". Komenský tak bere $v$ úvahu i kvalitativní vlastnosti věcí, dnes bychom řekli jejich bytnost, ve shodě s níž existují. Sledujme tuto myšlenkovou linii dále.

Věci získávají své podstatné vlastnosti již při Stvoření: „[...] toto nestvořené, v sobě samém přebývající, skryté, nezbadatelné a slovy nepopsatelné Světlo díky nezměrnosti své Moci mohlo a díky hlubině své Moudrosti umělo a díky nadbytku Dobroty chtělo vytvořit viditelné zpodobení své neviditelné Moci, Moudrosti a Dobroty tím, že vrhlo paprsky své záře mimo sebe a vtisklo je do stínu nicoty (jako do proti sobě postaveného zrcadla), určilo věcem [...] aby neměly $v$ nenávisti svůj počátek. [...] různým poměrným smíšením světla a tmy (tj. bytnosti a nicoty) byla na mnoha místech zobrazena ona prostá a nekonečná dokonalost věčné krásy." (Klosová, Schifferová, 1999).

Tak do skutečnosti vstupuje dobro a krása, které pak (z nitra této skutečnosti) působí jako důležité síly. Jsou $v$ rámci (Stvořitelem daného) řádu povolány $k$ obnově a zrodu nového, pokračování věcí a tedy i světa. ${ }^{21}$

prístupné absolutno - vše totiž vypovídá o všem. Pochopení prírody ale znamená harmonickou blízkost a kontakt, ne odtažitý odstup. Přistupujeme-li k př́rodě a danostem světa synkriticky, stanou se tyto našimi učiteli a poučí nás o naší vlastní úloze ošetřovat svět jako spravedlivý vládce, ne vykořistovatel (FILIT, 1999).

${ }_{19}$ Komenský ji rozpracoval v díle Dveře věcí otevřené (Janua rerum, 1643), které je po První filozofii (Prima philosophia) druhým známým Komenského pokusem o vypracování metafyziky (Klosová, Schifferová, 1999).

${ }^{20}$ Nikoli tedy následovat za fyzikou - toto pojetí by dle Komenského bránilo tomu, aby se metafyzika stala východiskem veškeré vzdělanosti. Metafyzika by měla být zároveň naukou o bytí a poznání Komenský ji považuje nikoli za scientia, nýbrž ars, která má normy, nikoli leges (Patočka, 1998, s. 249).

21 Dveře věcí otevřené (Klosová, Schifferová, 1999): „[...] hluboká a nepohnutá věčnost Stvořitele byla jistě málo vhodná pro vytváření i pro udržování stvořených věcí; proto stvořil Svět, jenž měl trvat mimo něj, rozměr a trvání posloupnosti, jejž nazýváme čas." „[...] protože chtěl, aby každé stvoření bylo vsobě jedno a bylo odlišené od jiných [...] přidal každé věci příslušné meze [...] [které se] 
(Božský) řád je tedy harmonií a cílem, v souladu s nímž se vše děje. Navíc má každá věc svůj zdroj existenciálního pohybu $v$ sobě samé, ten má původ ve vnitřních silách kvalitativní povahy. Jejich prostřednictvím vše samo sebe uskutečňuje, stále se obnovuje. Pokračování světa pak $v$ podstatné míře závisí na dobru a lásce, které jsou přítomny ve věcech samých 22 (srovnej též Patočka, 1997, s. 64-65).

\section{Tajemství}

Způsob, jímž poznáváme svět, je trojí:

„Trojí je pramen moudrosti: První, zdravý rozum, plný představ vrozených, jenž musí být přemýšlením osvětlován. Druhý vesmír, plný tvorů, který musí být smyslům podrobován. Třetí: zjevené nám tajemství, v němž pátrej věrou. [...] Komenský tedy učí vnitřním věcem skrze věci vnější. Tak mysl postihuje to, co větší částí svou se tají, a jen stopami, jež sem tam prokmitávají, se projevuje." (Pujman, 1942, s. 13).

$K$ nápravě světa, $k$ jednotě lidstva $v$ jednotné civilizaci, vytvořené jednotným světlem rozumu vede vševýchova, pampaedia, jež spočívá do značné míry, ne však plně na světle vševědy, pansofie. Komenský pokládá za nezbytné i světlo třetí, nejvyšší, které pomáhá všude tam, kde světlo věcí a mysli nestačí. Pansofie není možná bez knihy zjevení - jinak zůstane všechno vědění kusé - a má být doplněna světlem Světa věčného, ${ }^{23}$

kterým se teprve všenáprava a vševýchova stávají možné (Patočka, 2003, s. 208).

\section{Vševýchova a orientace $\mathrm{k}$ celku}

Těžištěm Komenského zájmu o vševědu je nejen snaha přehledně uspořádat dostupné poznání a zbavit vzdělání zmatků a nejasností, ale také poskytnout základ pro společenskou reformu. Jeho filozofické úsilí má mít praktické důsledky - ústí do soustavy vědění pro nápravu světa. Výuka, která sleduje tyto cíle, by ovšem měla být celková, musí učit celku a jeho smyslu. Má postupovat tak, aby se před očima udržoval smysluplný celek, od totality se postupovalo k propracování jednotlivostí. Názor - to je vhled do celku a jeho založení (Pešková, 2000, s. 43-44).

nazývají kvantita." „Když byly stvořené věci tímto způsobem zadržovány v sevření času, místa a svých mezí, musely by být zcela bez užitku [...] Aby Stvořitel osvobodil stvořené věci z těžkopádné strnulosti, vložil do všech jednotlivě určité síly, které na sebe jednak vnitru vzájemně působí, jednak se projevují navenek. A těm říkáme kvality." "A protože ty síly nemohou být nečinné, udílejí pohyb [...] Z toho pramení různé a ustavičné činnosti věcí [...]" "Tento tok sil se nevylévá do prázdna [...] kdekoli je činnost, tam Ize hned zároveň najít i trpnost. Jedna věc totiž vysílá svůj vliv, a druhá přijímá vyslanou sílu." "Aby podle záměru Stvořitele nevedly změny k všeobecnému zničení, ale i ke zrodům, a tak i k pokračování věcí, byl [...] přidán řád."

22 Dveře věcí otevřené (Klosová, Schifferová, 1999)://"A ztakto náležitě utř́iděného řádu nemohly vyplynout nic jiného než vhodnost či užitečnost věcí pro jejich cíle... "//"Stvořitel i stvoření pak pozoruji tento rádem stanovený chod věcí, užívají jej pro své cíle, a čerpají z něj potěšení. Obvykle se tomu říká láska či pưvab či př́jemnost, jež je ve věcech." //"Tak je devět nejvyšších náležitostí stvořených zcela zároveň s věcmi: čas, místo a kvantita; kvalita, činnost a trpnost; řád, užitek a láska."

${ }^{23}$ Svět věčný - takový, který se vrátil pod vládu Boží moudrosti, moci, milosrdenství a spravedlnosti, a který uzavírá cyklus pansofických světů. //,Učinit lidi mnohovědoucími: k tomu je trojí cesta [...] třetí cesta je nejméně snadná [...] 3. Porozumění idejím, jejichž prostřednictvím věci (obecné i jednotlivé) musejí být takové, jaké jsou, to činí lidi moudrými. [...] Takové vědění má Bůh, který od věčnosti do věčnosti ve všem vidí a pozoruje všechno, ze značné části $i$ andělé, kteří věci chápou bez dlouhého mluvení [...] My však musíme tyto tři cesty spojovat, ale stupňovitě." (Komenský, 1992e, s. 67).//„A poněvadž člověku jest dán duch obsáhlý (se svými částmi - rozumem, vưlí a pamětí) na způsob propasti, a poněvadž tuto propast nemůže zaplnit ani málo, ani mnoho věcí, potřebuje potravy nekonečné množství. Nerozsvítí-li se tedy nad touto propastí plné světlo, tu [...] propast zůstane propastí a nepřijme tvářnost krásného všehomíru. [...] Vpust́me tedy klidně plné trojí Boží světlo (všech Božích děl, zkoumaných smysly, dále světlo Boží svítilny $v$ nás, totiž daných rozumových pravd, a světlo Božích zjevení, přijatých vírou)." (Komenský, 1992e, s. 41). 
Takový přístup současně zajištuje před jednostranným zneužitím vědy - hlavním a jediným cílem vědění je přece pomáhat lidstvu. Tři úkoly pansofie tedy významně souvisí se vzděláním; jsou jimi: náprava škol, soulad učeného světa $v$ nesporných výsledcích vědy, náprava lidských společenských rádů.

„Jde o to, aby byli vyučováni [...] ve všem tom, co může člověka učinit moudrým a štastným. [...] Má-li se toto jeviště světa zcela změnit, je nutno, aby se od nejhlubších základů změnilo všechno lidské vzdělávání, a to těmi zpưsoby, které ukazuje pansofie." (Komenský, 1992e, s. 37)

Škola a výchova ústí v praxi - mají připravovat k reálným dovednostem, jimiž „mysl, ruka a jazyk zvládají skutečný svět a podrobují jej nejvyšším cílům". ${ }^{24}$

„Univerzální vzdělání - jím Ize dosáhnout všechno pro Boží obraz, člověka." (Komenský, 1992, s. 15).

"Osvícení všech lidí pravou moudrostí, k spojení s Bohem a pravým náboženstvím tak, aby se nikdo nemohl minout se smyslem svého poslání na svět." (Komenský, 1992e, s. 15).

"Nalézat nejvyšší dobro, jen sním se nerozlučně spojovat a tak dospívat k blaženosti. Stručně: Být rozumný pro věčnost a nebýt nerozumný pro svět." (Komenský, 1992e, s. 15).

V posledním období, kdy Jan Amos Komenský považuje svět za dílo nápravy, chápe člověka již ne jako diváka v divadle světa, ani jako zmateného poutníka v jeho labyrintech, nýbrž jako účastníka na jeho zásadní reformě. Náprava lidských věcí není jen dílem rozumu - Komenský $v$ duchu Mikuláše Kusánského (jeho odhalování nekonečnosti v konečném) trval na tom, že člověk není obrazem Božím jen rozumem a svobodnou vưlí, ale i určitou formou nekonečnosti. $V$ tomto kontextu se setkáváme $s$ nejpozoruhodnější Komenského definicí člověka, jako „svobodné bytosti, jež v nekonečnu nekonečně sama sebe tvoři". 25

\section{Závěr}

Pansofický základ, který pronikal všemi aspekty díla Komenského, byl rozvíjen v kontextu prakticky orientovaného úsilí, v souvislostech snah o celkovou obrodu života. Z tohoto hlediska se mohl stát hlubokou integrací světa prírodního, rozumového i duchovního. Komenskému nešlo pouze o vytvoření jednotné vědy. Myšlení a jednání, teorie i praxe se dle jeho filozofie měla orientovat ve směru nejvyšší pravdy, lásky a dobra, které teprve jednotu umožňují. ${ }^{26}$ Reforma společnosti prakticky ve všech oblastech pak zahrnuje reformu vzdělanosti a vědění. Pansofie je určena pro vzdělání všech - a tím směřuje $\mathrm{k}$ všenápravě (panorthosii).

\footnotetext{
24 "'Celistvě vzdělán - člověk vycvičen ve všech věcech, které dovršují podstatu lidskosti, aby dovedl vědět pravdu, milovat dobro, konat, co máme konat, [...] s věcmi, lidmi a s Bohem jednat ve všem rozumně, ne unáhleně, a tak se nikde neuchylovat od cíle svého štěstí." (Komenský, 1992e).// "Nebot' svět už opravdu bude moci mít neuhasitelné světlo, jaké si přál Šalamoun (Mdr 7, 10), poněvadž je do nekonečna rozmnožitelné [...] Budou napraveny stezky těch, kteří jsou na zemi, když se naučí všichni lidé i každý zvlášt́ tomu, co se líbí Bohu (Mdr 9, 18). A svět konečně přestane být tupý, bez smyslu, bez rozumu, bez náboženství, světský a bezbožný, podrobený zmatkům a zlořečení." (Komenský, 1992e, s. 143).

${ }_{25}$ Producenda fuit creatura indeterminata in infinito infinite seipsam agens (Komenský, 1992c). Viz též: < http://www.phil.muni.cz/fil/scf/komens.html>

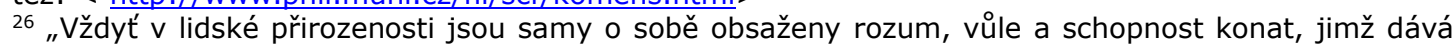
potravu pravda, dobro a jednota, čili jednotící síla (to je možnost)." (Komenský, 1992e, s. 41).
} 
Ve své době byl Komenský v úmyslné opozici vưči tzv. racionalistické filozofii, která postupně převládla. ${ }^{27}$ Znal Descartesa a jeho metodickou reformu, ale rozhodně je odmítal - nestačil mu vnější mechanistický pohled na skutečnost, a to zejména v oblasti lidské. Záleželo mu především na vnitřním pohledu do struktur věcí, který vede k pochopení celku. Zabýval se vztahy kvalitativních a kvantitativních činitelư; ty měly být obsaženy již ve světě materiálním i ve všech lidských "světech". Vybudoval vlastní univerzalizmus; poznal totiž, že matematicky nelze všechno vyložit (Čapková, 1992, s. 32). Součástí jeho myšlenkové stavby pak bylo ovšem i to, co není možno plně pochopit: ${ }^{28}$ co vychází $z$ harmonie, získává svůj řád $v$ souladu $s$ dobrem, a směřuje $k$ užitku, jemuž před zneužitím zabraňuje láska. To se plně projevuje $v$ Komenského originálním triadickém systému. ${ }^{29} \mathrm{~K}$ procesu poznávání zahrnujícímu theoria - praxis $\mathrm{v}$ rámci tohoto trojdělení patři také třetí člen, chrésis, moudrost a prozíravé užívání ve shodě s celkovým úkolem nápravy všeho (Čapková, 1999, s.100-102; Patočka, 2003, s. 174).

Komenský zůstal po celý život na opačném pólu proti karteziánskému subjektivizmu a jeho pojetí pravdy. To se mu jevilo „extrémem té nepravosti, z níž pramení všechny naše zmatky a bědy: snahy být si sám vlastním středem."30 (Patočka, 1992, s. 560). Nebyl mistrem dobové vědy; jeho teorie vyučování však přispěla k tomu, že vznikla samostatná věda pedagogická. Stále v platnosti pro oblast výchovnou zůstávají dvě ústřední myšlenky, jež mají základ $v$ Komenského pansofii: příroda jako tvưrce forem; a paralelizmus mezi aktivitou lidskou a prírodním děním. Tento rámec pozdější pedagogické výzkumy rozšiřovaly, uváděly do jiného kontextu, nikdy jej však nepřekonaly (Piaget, 1993).

V myšlenkovém světě Komenského byl dobový trend - uskutečnit panství člověka nad přírodou - spojen se zdůrazněním, že člověk má zároveň vládnout také sobě samému. Má být tedy přiveden k odpovědnosti ve vztahu k přírodě, klidem, k Bohu, jehož vůli je třeba rozpoznat. Pak nabude na významu nikoli vláda, ovládání, ale naopak služebnost, správa ve vztahu člověka k přírodě i klidem (Čapková, 2002).

27 Komenského dílo tak již ve své době nebylo náležitě doceněno: „Bylo by Ize říci, že upadl-li Komenský $v$ zapomenutí již v 70. letech 17. století, souvisí to s proměnou epistemologického pole, s niž neudržel krok." (Patočka, 1967).

${ }^{28} \mathrm{~V}$ úvahách o kategoriích reálných jsoucen si Komenský všímá podstat, ale také případků, například času, místa, kvantity, velikosti. „[...] podobně můžeme přemýšlet o kvalitě, činnosti, trpnosti, užitku a lásce, ale nemůžeme je pochopit. Každá z nich zjevně obsahuje rys něčeho nekonečného." (Komenský, 1992, s. 322-323).

${ }^{29} \mathrm{~V}$ tomto přístupu byl Komenskému vzorem nejen Mikuláš Kusánský (jeho triáda materia - forma conexio), a také božská trojjedinost. Komenského triáda ordo - usus - amor (řád - užitek - láska) se nevyskytuje v žádné jiné metafyzice, Komenský jí nahradil běžné kategorie relatio - situs - habitus. Tato triáda je uváděna ve Světě možném i v Janua rerum zroku 1681.

${ }_{30}$ "V souladu $\mathrm{S}$ klasickou filozofickou tradicí soudí Komenský, že je tedy třeba obratu, který bude jedině tenkrát vskutku účinný, když přivede věci i člověka $k$ jejich celkové, věčné, nutné podobě. Toho se nedá dosáhnout, jak si filozofové, moralisté, politikové, teologové minulosti představovali, nějakým individuálním obratem vmysli nebo nápravou pouze některé ze stránek lidského života; tak například utopisté si vždy představují nápravu státu, politeie, jako východisko obratu všeho. Ve skutečnosti jsou však tři na sebe nepřevoditelné, základní vztahy člověka, které současně a týmž způsobem jsou porušeny, nepravdivé a zlomkovité, které je tedy třeba zároveň a stejným způsobem přivést $\mathrm{k}$ tomu, aby přebývaly ve své podstatě, aby se kryly s tím, co $v$ nich je jednotného a všeobsáhlého, tedy věčného: vztah $k$ věcem, vztah $k$ druhým lidem a $k$ tomu, co je nad člověkem [...] Všechny tyto vztahy je potřeba rázem, zároveň obrátit od mnohosti, roztříštěnosti, zlomkovitosti, necelosti $\mathrm{k}$ jednotě a celistvosti: to je univerzalizmus Komenského. Klasický racionalizmus, který chce napravit lidské věci tím, že všem lidem před oči postaví týž jednotný, rozumově odůvodněný cíl, cíl jednoty, má tedy v podstatě pravdu, byl pouze nedokonale proveden." (Patočka, 1992, s. 546). 


\section{Literatura}

- Čapková, D. (1983). Myšlenka lidské aktivity v Komenského pojetí dějin. Praha: Academia.

- Čapková, D. (1992) Úvod : Komenského Obecná porada a její význam. In Komenský, Jan Amos. Obecná porada o nápravě věcí lidských. I. sv.. Praha: Svoboda.

- Čapková, D. (1999). Ordo - Usus - Amor : K otázce propojování některých triadických principů pansofické metafyziky a jejich uplatňování voblasti lidské činnosti. Studia Comeniana et Historica, 29(62), 99-103.

- Čapková, D. (2002). Anglický milenarismus a Komenský. Studia Comeniana et historica, 32(67-68), 37-43.

- Comenius, J. A. (1974) Faber fortunae sive Ars consulendi sibi ipsi : Itemqve Regulae Vitae Sapientis. Amstelodami, Ex officina Petri van den Berge. In O. Říha (Ed.), Dílo Jana Amose Komenského 13. Praha: Academia.

- Piaček, J., Kravčík, M., (1999). Filit: Otvorená filozofická encyklopédia, Verzia 4.0. . Retrieved from http://ii.fmph.uniba.sk/ kravcik/filit/

- (2007). .

- Janoušek, H. (2005). A. Koyré : Od uzavřeného světa k nekonečnému vesmíru.. Reflexe [online], 29, 149-154.

- Komenský, J. A. (1992). Obecná porada o nápravě věcí lidských. Sv. 1.. Praha: Svoboda.

- Komenský, J. A. (1992). Obecná porada o nápravě věcí lidských. Sv. 1.. Praha: Svoboda.

- Komenský, J. A. (1992). Obecná porada o nápravě věcí lidských. Sv. 1.. Praha: Svoboda.

- Komenský, J. A. (1992). Obecná porada o nápravě věcí lidských. Sv. II.. Praha: Svoboda.

- Komenský, J. A. (1992). Obecná porada o nápravě věcí lidských. Sv. III.. Praha: Svoboda.

- Kopecký, J., Kyrášek, J., Singule, F., Spěváček, V., (1969) Jan Amos Komenský : 15921670.. In Kapitoly z dějin pedagogiky (pp. 56-68). Praha: SPN.

- Kumpera, J. (1999). Poselství J. A. Komenského pro vzdělanost a humanitu dneška (Referát přednesený na konferenci Obecná porada 1999 - Sto let uprostřed Evropy). Praha: UK, Nadace Pangea.

- Kyrášek, J. (1964). Synkritická metoda v díle J. A. Komenského. Praha: Nakladatelství Československé akademie věd.

- Moskalová, J. (2005). Harmonie Jana Amose Komenského. Paideia, 2(4), Retrieved from http://userweb.pedf.cuni.cz/paideia/index.php?sid=3\&lng=cs\&lsn=10\&jiid=7\&jcid $=41$

- Patočka, J. (1967). Slova a věci : rozbor antropologické epochy evropského myšlení v "archeologii" Michela Foucaulta.. Světová literatura, 12(6), 229-234.

- Patočka, J. (1995). Tělo, společenství, jazyk, svět. Ze záznamů přednášek proslovených ve školním roce 1968-69 na Filozofické fakultě Univerzity Karlovy sestavil Jiří Polívka. Praha: ISE.

- Patočka, J. Komenského Všeobecná porada. In Komenský, Jan Amos. Obecná porada o nápravě věcí lidských. III. sv. 1.. Praha: Svoboda.

- Patočka, J. (1997). Komeniologické studie : Soubor textů o J.A. Komenském.1. díl, k vydání připravila Věra Schifferová. Praha: OIKOYMENH. 
- Patočka, J. (1998). Komeniologické studie : Soubor textů o J.A. Komenském.2. díl, k vydání připravila Věra Schifferová. Praha: OIKOYMENH.

- Patočka, J. (2003). Komeniologické studie : Soubor textů o J.A. Komenském.3. díl, k vydání připravila Věra Schifferová. Praha: OIKOYMENH.

- Piaget, J. (1993). Jan Amos Comenius. Prospects (UNESCO, International Bureau of Education) [online]. .

- Pešková, J. (1991). Filozofický základ Komenského díla. Studia Comeniana et historica, 21(44), 69-74.

- Pešková, J. (2000). Obraz Jana Amose Komenského u Tomáše Garriguea Masaryka a Jana Patočky : významná inspirace pro českou filozofii a filozofii výchovy na přelomu století. Studia Comeniana et historica, 30(63-64), 42-46.

- Pujman, F. (1942). Komenský a Cartesius. Praha: Novina.

- Klosová, M., \& Schifferová, V. (1999). Jan Amos Komenský : dveře věcí otevřené (1643). Studia Comeniana et historica, 29(62), 211-226.

- Válka, J. . Descartes a Komenský ve změně myšlenkových paradigmat na prahu moderny. Studia Comeniana et historica, 26(55-56), 197-205.

\section{Recenzní posudky (slovní hodnocení příspěvku)}

\section{Recenzent 1:}

Věra Schifferová - Filozofický ústav Akademie věd ČR

„Cílem stati je upozornit na některé Komenského myšlenky, které by mohly inspirovat současnou pedagogickou diskuzi zaměřenou k environmentálním otázkám. Tím stat' velmi dobře vyhovuje tematickému zaměření časopisu. Stat' je jak po stránce formální, tak po stránce obsahové zpracována na náležité úrovni. Drobné připomínky byly předány autorce stati. Autorka stati svou hlavní pozornost věnuje Komenského pansofii založené na pojetí světa jako jednotného a harmonického celku a Komenského univerzalizmu. Upozorňuje, že Komenský se tu výrazně odlišuje od dobového racionalizmu, který od sebe oddělil to, co právě u Komenského je $v$ jednotě, totiž "svět hodnot a svět faktư". Komenský na rozdíl od hlavních představitelů racionalizmu 17. století neusiloval o mocenské ovládnutí světa, nýbrž o znovuobjevení porušené jednoty a harmonie člověka s Bohem, prírodou a ostatními lidmi. Komenského dílo, jak autorka upozorňuje, mủže poskytnout řadu podnětů k promýšlení otázek souvisejících $s$ některými dehumanizačními účinky moderního vědeckého a technického rozvoje. Autorka v této souvislosti připomíná některé negativní aspekty novověké vědy, jako např. separovanost vědeckých disciplín ztrácející ze zřetele odpovědnost člověka za jeho konání a jednostranný důraz na kvantitativní kritéria vědeckého bádání. Největší přínos Komenského autorka shledává $\checkmark$ tom, že nikdy neztratil ze zřetele etickou dimenzi vědy a vzdělávání. Autorka ve stati položila otázku, čím může Komenský oslovit člověka dnešní doby. Odpověd' jí nastíněná, oceňující hlavně Komenského metodu celkovosti, je $v$ souladu $s$ výsledky soudobého filozofického výkladu Komenského."

\section{Recenzent 2:}

Recenzent nesouhlasí se zveřejněním jména.

„Autorka připomíná pansofické úsilí J. A. Komenského a poukazuje na jeho pojetí celostní výchovy zaměřené na aktivní účast ve světě. Dưraz je kladen na klíčovou roli 
hodnoty odpovědnosti ve výchově - odpovědnosti člověka ve vztahu klidem, k přírodě, $\mathrm{k}$ Bohu. Autorka svým textem vznáší naléhavou otázku aktuálnosti principů všenápravného díla J. A. Komenského, $v$ němž namísto vlády a moci nově budující se mathesis universalis měla nastoupit orientace výchovy a vzdělávání na (znovu)pochopení a přijetí služebné a spravující role člověka ve světě." 
Časopis Envigogika vydává Centrum pro otázky životního prostředí UK. Vývoj časopisu je podpořen projektem OP VK Mezioborová sít udržitelného rozvoje.

Více najdete na internetových stránkách projektu mosur.czp.cuni.cz
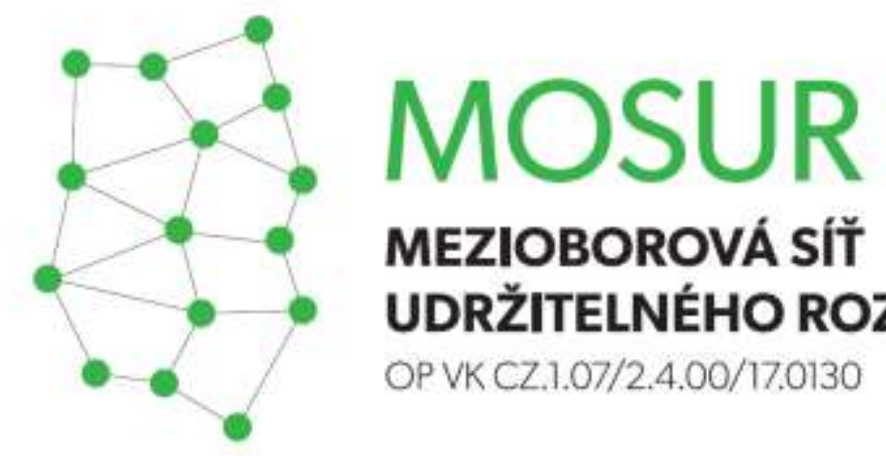

\section{MEZIOBOROVÁ SÍT} UDRŽITELNÉHO ROZVOJE

OP VK CZ.1.07/2.4.00/17.0130
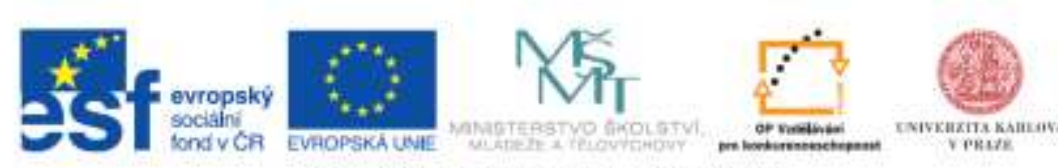

INVESTICE DO ROZVOJE VZDELAVANI 